\title{
Co-current combustion of oil shale - Part 2: Structure of the combustion front
}

\author{
M.F. Martins ${ }^{\mathrm{a}, *}$, S. Salvador ${ }^{\mathrm{a}}$, J.-F. Thovert ${ }^{\mathrm{b}}$, G. Debenest $^{\mathrm{c}, \mathrm{d}}$ \\ a Université de Toulouse, MINES ALBI, RAPSODEE UMR CNRS 2392, Albi F 81013, France \\ ${ }^{\mathrm{b}}$ LCD, Ecole Nationale Supérieure de Mécanique et d'Aérotechnique, 86961 Futuroscope Chasseneuil cedex, France \\ ${ }^{\mathrm{c}}$ Université de Toulouse; INPT, UPS; IMFT (Institut de Mécanique des Fluides de Toulouse), Allée Camille Soula, F-31400 Toulouse, France \\ ${ }^{\mathrm{d}}$ CNRS, IMFT, F-31400 Toulouse, France
}

\begin{abstract}
A B S T R A C T
Timahdit oil shale was used as a porous medium to characterize the structure of a combustion front propagating with co-current downward air supply. A new 1D experimental device was first calibrated using a model porous medium. With the model porous medium, the front propagates as a plane and horizontal surface while using oil shale the front propagates as an inclined curved surface. The peak temperature was $1100^{\circ} \mathrm{C}$; despite the relatively large diameter of the cell $(91 \mathrm{~mm})$ and the good thermal insulation, the heat losses were estimated at $42 \%$ of the heat released by the combustion. The thickness of the front was characterized using a new gas micro-sampling system: the char oxidation and the carbonate decarbonation zones are approximately 10 and $15 \mathrm{~mm}$ thick, respectively. The oil formed during the pyrolysis is adsorbed in the porous medium in the course of the experiment, and expulsed from the cell by the end.
\end{abstract}

Keywords:

Oil shale

Combustion front

Smoldering

Front structure

Reactive porous medium

\section{Introduction}

The propagation of a combustion front occurs in a variety of situations and for different purposes, such as waste incineration, in situ combustion or burning of solid fuels for other industrial applications. Description of the front in a reactive porous medium remains a challenge to science in terms of physicochemistry, and heat and mass transfer of the combustion front propagation.

A pioneering work was accomplished by Palmer [1]. According to [2], the first great research effort in combustion front propagation dates from 1977 to 1979. Since then, most of research in smoldering combustion of porous media has been conducted in the field of fire science and fire safety engineering [3,4]. Familiar environmental problems and the search for alternative energy sources have also motivated research on the subject. These efforts have focused on determining which parameters influence the progress and structure of a combustion front. To this effect, some authors have developed numerical models and experimental devices.

The present work focuses on the propagation of a combustion front in a reactive porous medium [1,3-7]. In this type of problem, the solid phase reacts with the gas phase; chemical reactions occur, such as pyrolysis of the solid and further oxidation of the residual carbon, accompanied by extreme changes in the physical structure of the solid phase.

In this sort of problem, two elementary combustion situations can be distinguished: counter-current combustion (or opposed com-

\footnotetext{
* Corresponding author. Tel.: +33 5634930 26; fax: +33 563493242 . E-mail address: marcio.martins@enstimac.fr (M.F. Martins).
}

bustion), where ignition front and feed of primary air occur on opposite sides of the fuel batch. The counter-current air supply is normally found in fixed-bed combustion processes. The typical application of counter-current combustion is the incineration of municipal solid waste [8-11]. In the second case, co-current combustion (or forward combustion), both combustion front and feeding of primary air take place on the same side of the combustion cell $[12,13,6]$. This last case is investigated in this work. The best example of co-current combustion can be found in situ combustion for oil recovery $[14,15]$.

Only a handful of experimental works on co-current combustion have been carried out until now. Vantelon et al. [7] made an experimental study on the forward combustion of a bed of tires and refractory briquettes. The author found that the combustion process is influenced by the airflow rate through the reactor. An oxygen-limited combustion reaction moves from a rate-limited regime to a heat transfer-limited regime. The rate-limited regime is characterized by high production of residual oil and low propagation velocities. The heat transfer-limited regime reduces the production of oil, but it results in a much faster conversion of the fuel. Two other different regimes are also observed as a function of the mass fraction of tires.

- For mass fractions of tires less than 70\%, the final tire conversion rate and temperature are proportional to the mass fraction of tires. In this regime the volumetric energy density dominates the combustion process.

- For a mass fraction of tires greater than $70 \%$, the conversion rate is independent of the amount of fuel and it is initially much 
slower than for lower fuel concentrations. These two regimes could be described in a qualitative manner by a simple energy balance.

In a recent study, Pironi et al. [16] performed forward smoldering experiments using a mix of coal tar in inert media as the fuel, and provided valuable insights into the properties of the combustion front. With regard to the case of counter-current combustion, several experimental devices have been developed for the investigation of combustion front propagation and structure. Although this configuration will not be studied here, its results may be interesting for the present work.

Gort et al. [17] studied the influence of the superficial air velocity and moisture content on three fuels: coke, wood and shredded municipal waste. The experiments were carried out in a laboratory grate furnace. He suggested three reaction regimes:

(i) partial gasification where, after oxygen depletion, there is still some solid material left, which might be partially consumed by gasification by $\mathrm{H}_{2} \mathrm{O}$ and $\mathrm{CO}_{2}$;

(ii) complete gasification where air flow rate is high enough to convert all ignited material, but there is not enough oxygen available for complete combustion of unburnt gases;

(iii) combustion regime where initially some $\mathrm{CO}$ is observed, but this is oxidized quickly. Concentrations fluctuate strongly. The reaction layer is thin.

Shin and Choi [18] proposed a similar concept on the countercurrent propagation of a combustion front. The combustion of solid fuel in a fixed bed was investigated using one-dimensional experiments. The effects of air supply rate, fuel particle size and the calorific value are discussed. Two modes of combustion in the bed can be distinguished, based on the availability of oxygen. Oxygen-limited combustion: at low rates of air supply, the oxygen is completely consumed by the char and the reacting volatile material. In this case, the reaction rate of the fuel is determined by the oxygen supply rate. Reaction-limited combustion: if the air supply is increased, combustion is further enhanced, but the limit of the combustion rate of the bed material causes an increased oxygen concentration at the exit. In this case, the reaction rate cannot increase further owing to the limit of the reaction rate and the increased convective cooling by the air. They proposed a schematic, to show how the combustion depends on the air supply rate.

Liang et al. [19] reported another important aspect concerning the heterogeneity of the composition of the solid particles. For the sample extracted in different parts of corn straw, the concentration of $\mathrm{CO}$ and NO are clearly different. According to the author, corn straw combustion occurred in two stages: ignition front propagation and char oxidation. Both stages were identified by $[20,21,8]$.

\subsection{Choice of the porous medium}

One of the first difficulties met by the experimenter aiming to achieve accurate trials is the geometrical stability of the reacting bed. Most of the usual materials constituting a bed will undergo a drastic shrinkage along the pyrolysis/combustion process. As a consequence, the overall diameter of the bed will decrease, and the air flow forced into the cell will not impose a well-controlled velocity on a cross section of the bed: air will circulate preferentially around the bed. The only material we identified that preserves its geometry along the combustion process is oil shale; we measured vertical shrinkage of the bed at only $3.5 \%$. Consequently, one can expect to maintain a 1D situation. Moreover, there is only a slight change in the porosity of the bed after combustion, which would make the situation less complex if modeling were undertaken.
Oil shales are sedimentary rocks containing relatively large amounts of organic matter called kerogen, [22-24], from which significant amounts of shale oil and combustible gas can be extracted by pyrolysis up to $500^{\circ} \mathrm{C}$.

\subsection{Objectives of the work}

As far as the structure of the combustion front in an oil shale crushed bed is concerned, only one small piece of literature is available. Debenest et al. [25] conducted an experiment, in which they could follow a reaction front visually as it propagated upwards, with a glowing layer about three times the particle diameter. Nevertheless, such an observation does not allow the thickness of a reaction zone to be evaluated.

The main objective of this work is to propose a geometrical description of the different zones composing the front. Information is also expected about the temperature levels reached and the pressure drop inside the bed generated by the front. The behavior of liquid oil was also investigated, as its presence inside the medium may impact on the pressure drop.

These results, together with detailed characterization of OS and of the products of its pyrolysis, Submitted paper [26], should constitute a detailed benchmark, enabling modeling of this process in future works.

To operate the combustion of a porous medium in a controlled situation, a specific, highly instrumented experimental device was developed and calibrated using a model porous medium.

\section{Experimental device}

The French Standards Association (AFNOR) published the standard NF M 03-049, which deals with characterization of solid combustibles in a fixed bed in counter-current flow. The norm is based on the measurement of front velocity, combustion rate, pressure drop and temperature. According to the norm, the reactor should preferably have a cylindrical shape with a diameter of not less than $25 \mathrm{~cm}$, in order to avoid excessive influence of the wall on the results.

An experimental device was developed to enable 1D co-current experiments; see Fig. 1. It consists of a vertical cylindrical combustion chamber of $91 \mathrm{~mm}$ internal diameter and a height of $300 \mathrm{~mm}$. The diameter was chosen to be wide enough to limit heat losses through the walls, but narrow enough to avoid the preparation of large sample quantities, and also to facilitate treatment of the flue gas. It is made of a $2 \mathrm{~mm}$-thick stainless-steel material, surrounded by two types of insulating material: a $3 \mathrm{~mm}$ thick layer of wool (Superwool 607 blanket, Thermal Ceramics, $k=0.28 \mathrm{Wm}^{-1} \mathrm{~K}^{-1}$ at $982^{\circ} \mathrm{C}$ ) and a $50 \mathrm{~mm}$-thick layer of refractory fiber bloc (Kaowool HS 45 Board, Thermal Ceramics, $k=0.21 \mathrm{Wm}^{-1} \mathrm{~K}^{-1}$ at $1000^{\circ} \mathrm{C}$ ).

A grate is located at the bottom of the chamber and consists of a stainless-steel mesh. It is supported by an inner ring, which in turn is supported by the lower cone of the reactor. At the bottom of the cell is a flexible tube connected to reservoirs to condense and collect liquid oil. The air entry is designed to supply uninterrupted airflow in a symmetrical way; see Fig. 2A. Gas analyzers can be momentarily connected at the exit of the condensers to analyze $\mathrm{CO}$ and $\mathrm{CO}_{2}$ by NDIR, $\mathrm{O}_{2}$ using paramagnetism, methane plus non-methanic hydrocarbons (NMHC) using two FID detectors and $\mathrm{H}_{2}$ using gas chromatography.

The pressure at the top of the reactor and the total mass of the cell are continuously recorded.

\subsection{Temperature measurements}

The reactor is finely instrumented. A group of six in-line thermocouples $0.96 \mathrm{~mm}$ in diameter (T1, T2, T3, T10, T11 and T12) 


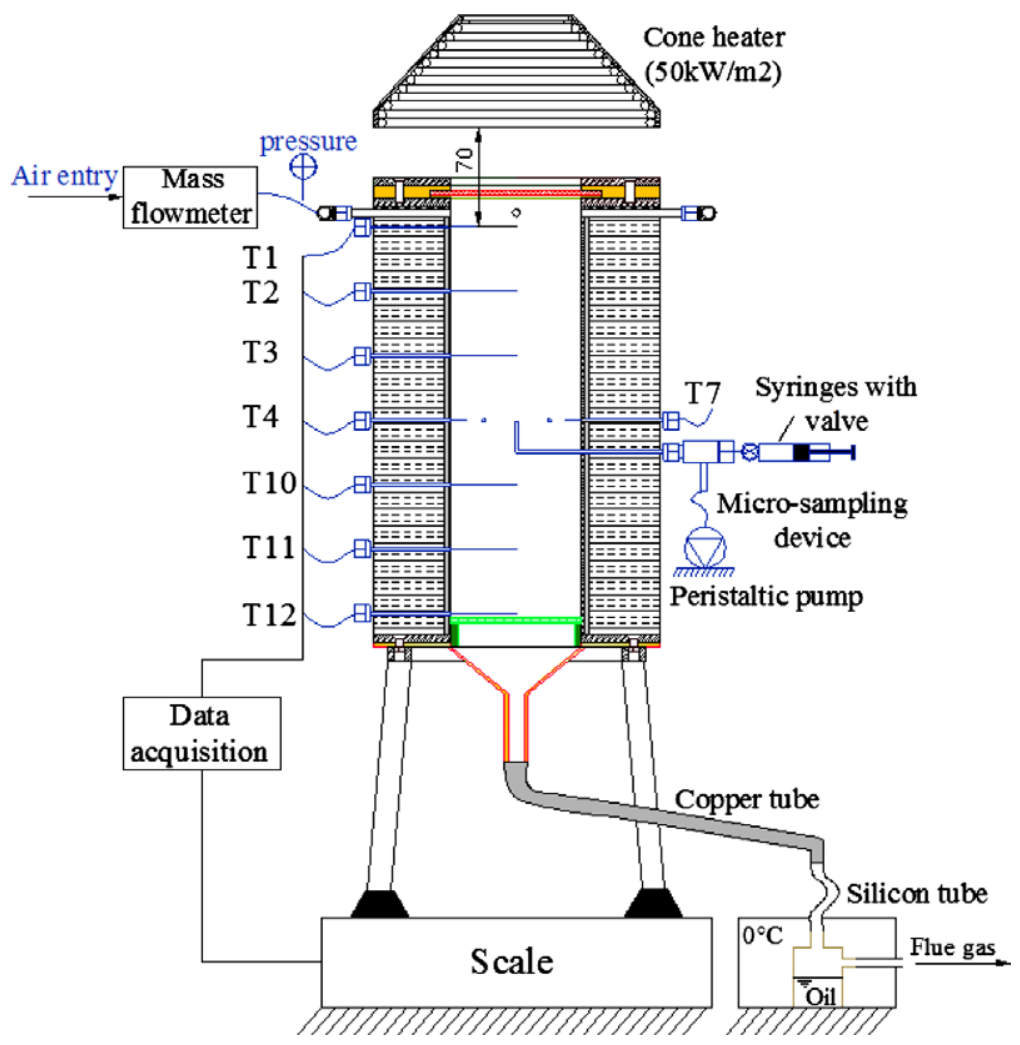

Fig. 1. Cell of combustion in porous medium, with micro-sampling system.

A

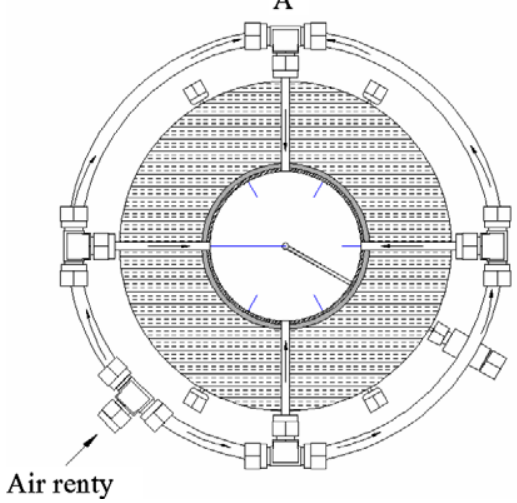

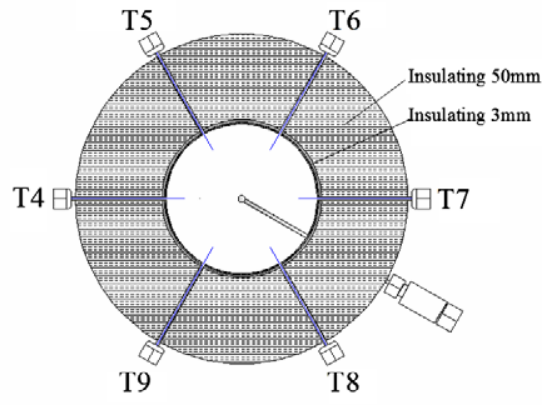

Fig. 2. Horizontal cut on the level of the air entry. (B) Horizontal cross section at middle height of the cell (details: micro-sampling system and crown thermocouple).

are located at $z=0,45,90$ and 180,225 and $270 \mathrm{~mm}$ (from top to bottom of the reactor), making it possible to measure the temperature along the axis of the cell at different heights. A crown of six thermocouples, identical to the ones previously mentioned, makes it possible to measure the temperature over a horizontal cross section (at approximate middle height, $z=135 \mathrm{~mm}$ ) $11 \mathrm{~mm}$ away from the walls: this will reveal whether the combustion front progresses or not as a horizontal surface.

\subsection{Ignition of the combustion}

To start a uniform front across the whole surface of the bed, a sophisticated ignition device is used, called a Cone Calorimeter. A radiative flux is generated by a metal surface called a cone heater. The radiant cone heater temperature is adjusted to $845^{\circ} \mathrm{C}$ to impose a heat flux of 45 to $50 \mathrm{k} \mathrm{W} \mathrm{m}^{-2}$ over the top surface of the oil shale. The cone heater has previously been calibrated using a water-cooled fluxmeter. The radiative flux crosses a quartz porthole that ensures the sealing of the closure, as shown in Fig. 3. The time of irradiation was $220 \mathrm{~s}$, controlled by opening/closing the insulator shield.

\subsection{Micro-sampling system}

A new and original device was developed and set up to improve the physicochemical investigation of the structure of the front. This micro-sampling device is shown in Figs. 1 and 2. Its originality lies in its ability to micro sample gas at a fixed point inside the chamber before, during and after the passage of the combustion front.

A peristaltic pump sucks gas at the axis of the reactor - at midheight - through a $1.6 \mathrm{~mm}$ internal tube. The flow rate is fixed at $2.0 \mathrm{ml} \mathrm{min}^{-1}$ at $20^{\circ} \mathrm{C}$, corresponding approximately to isokinetic 


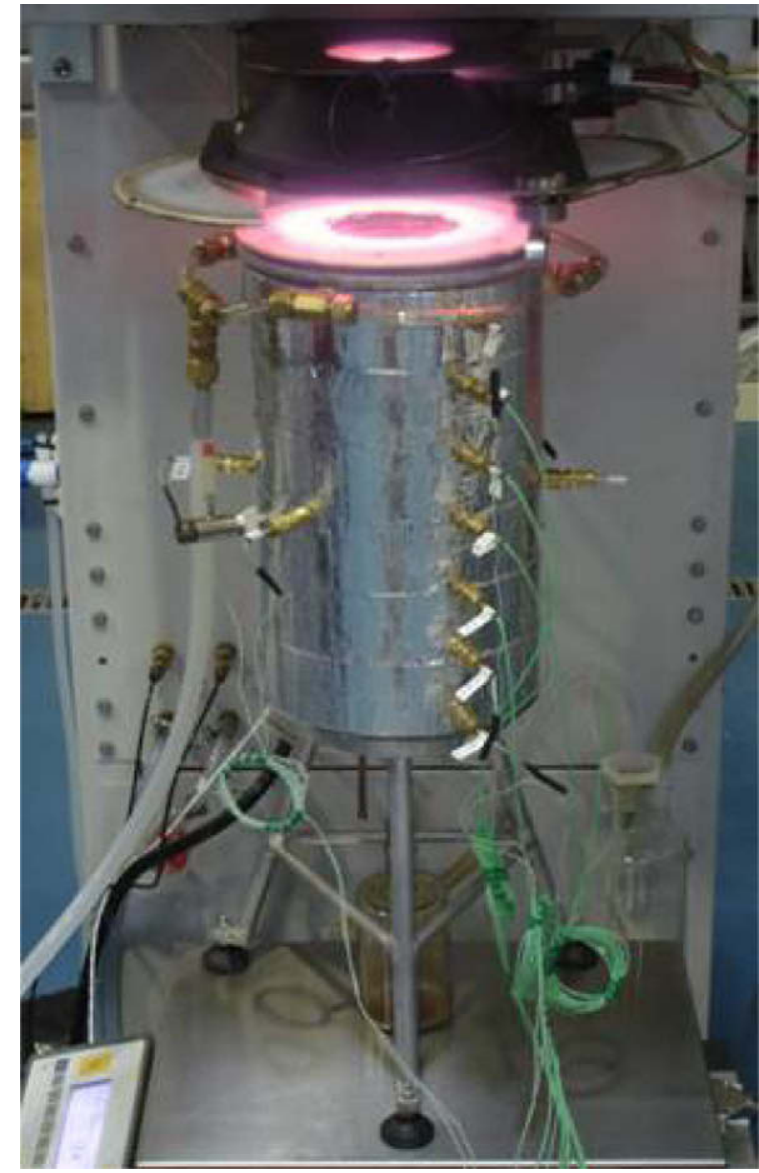

Fig. 3. Photograph at the time of irradiation of the oil shale surface.

sampling inside the bed, in order to minimize the perturbation of the front. The sampled gas is driven to an automatic septum. The dead volume of the sampling tube $(1.6 \mathrm{~mm}$ internal diameter, $166 \mathrm{~mm}$ long) and of the septum was $0.8 \mathrm{ml}$. Syringes of $0.25 \mathrm{ml}$ $(250 \mu \mathrm{l})$ with valves are used to sample gas inside the dead volume. A sample is taken every $30 \mathrm{~s}$; during that period, the front progresses by $1.25 \mathrm{~mm}$ approximately, which gives an optimistic evaluation of the spatial resolution of the system. The components $\mathrm{CO}$ and $\mathrm{CO}_{2}$ are analyzed a posteriori by gas chromatography.

\section{Calibration of the combustion cell using a model medium: charcoal/sand}

Oil shale is a complex reactive medium; its combustion involves drying, devolatilization, fixed carbon (FC) oxidation and carbonate decarbonation. Therefore, it was decided firstly to validate the combustion cell using as "simple" a model porous medium as possible. To simulate the FC, charcoal particles were used and mixed with sand. The sample was prepared by pyrolyzing wood chips, grinding the chips, and then selecting the particle size in the range $500-1000 \mu \mathrm{m}$. To obtain a homogeneous mix of charcoal particles with sand, it was necessary to prepare a kind of mortar by wetting the mix of charcoal and sand, before intensively mixing the mortar, then placing it into the combustion cell before drying it overnight. It was confirmed that after drying, the charcoal particles collected from the dry mortar - contained more than $91.6 \%$ of carbon. The mass proportion of carbon was $3.6 \%$, corresponding to experiments done later with the mix of oil shale and sand. This was obtained by introducing $2256 \mathrm{~g}$ of sand and $84.3 \mathrm{~g}$ of charcoal (dry base) in the cell.


Fig. 4. (A) Temperature evolution of the thermocouples placed along the axis and placed a horizontal cross section. (B) Mass and pressure evolution in the bed.

The experiments were run with an air flow rate of $9.51 \mathrm{~min}^{-1}$. This corresponds to a flow rate of $1460 \mathrm{l} \mathrm{min}^{-1}$ for $1 \mathrm{~m}^{2}$ of section, and to a Darcy velocity of $0.024 \mathrm{~m} \mathrm{~s}^{-1}$ at $20.0^{\circ} \mathrm{C}$, or $0.108 \mathrm{~m} \mathrm{~s}^{-1}$ at $1000{ }^{\circ} \mathrm{C}$. After combustion, the axial shrinkage of the bed was $16 \%$, which is not negligible. The analysis of the solid residue indicated that no more carbon was present (less than $0.05 \%$ in the mix of solid residue + sand). In this case, all the FC had been oxidized.

Fig. 4A shows the temperature evolution at several locations inside the bed for two experiments in the same conditions. For thermocouple T1, a peak close to $610^{\circ} \mathrm{C}$ was observed. For the other thermocouples placed along the axis (T2, T3, T10, T11 and T12), temperature peaks were observed near to $1050^{\circ} \mathrm{C}$.

On the horizontal cross section at the mid-point of the height of the bed (T4-T9), one can see that the temperature peak has fallen to $930{ }^{\circ} \mathrm{C}$ : the temperature difference compared to the axis of the bed is about $120^{\circ} \mathrm{C}$. This reveals significant heat losses through the walls.

The peak temperature is reached at the same time for all thermocouples of the crown, indicating that the front propagated as a horizontal surface. Moreover, the peak time for all thermocouples of the crown is midway between T3 and T10 peak time. This indicates that the front was a plane surface.

Fig. 4B shows the temporal evolutions of the pressure at the top of the particle bed for two experiments. The pressure increased almost linearly along the experiment, and decreased slightly at the end. An explanation might be that the average temperature level inside the bed increases with time, increasing the gas velocity and viscosity, and ultimately leading to pressure drop. When the front reaches the bottom of the cell, the top of the cell has started to cool down, as can be observed in Fig. 4A. This explains the decrease of the pressure by the end of the experiment. 

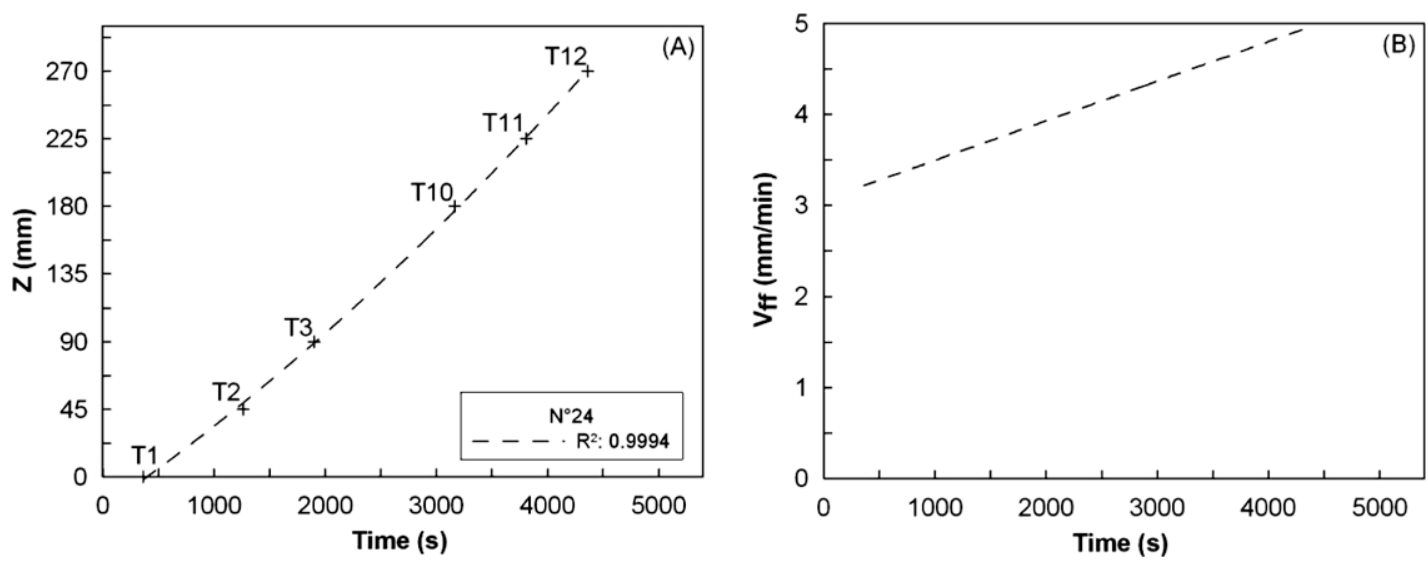

Fig. 5. (A) Curve fitting with its 1 st derivative at time. (B) Combustion front velocity.

The velocity of the front was determined from the data of passage at each thermocouple on the axis of the cell. A quadratic polynomial function giving the position of the combustion front versus time was fitted to the experimental points, as illustrated in Fig. 5A. The $r^{2}$ was better than 0.995 . The time derivative of this function is the velocity of the combustion front, shown in Fig. 5B. As indicated by the plots, the velocity of the front increased from 3.21 $\mathrm{mm} \mathrm{min}{ }^{-1}$ at the beginning of the experiment to $4.84 \mathrm{~mm} \mathrm{~min}^{-1}$ by the end. Al-Saffara et al. [27] found a similar trend. Torero and Fernandez-Pello [4] also reports this acceleration during forward smolder of polyurethane foam in a forced air flow.

\section{Propagation of a combustion front in OS packed bed}

A mass of $2127 \mathrm{~g}$ of mix 75/25 wt. oil shale/sand was introduced in the cell. The experiments were run again in an air flow rate of $9.51 \mathrm{~min}^{-1}$ at STP.

\subsection{Observation of the liquid oil produced and of the solid residue}

\subsubsection{Liquid oil}

The smoke was transparent until the front reached the middle of the cell; it then started to change of color to a dense white, and condensation of water appeared inside the tubes. After that, the smoke became yellow and at the moment $t=3490 \mathrm{~s}$ the first oil drops fell down inside the container.

At the end of the experiment, liquid oil was recovered in the reservoir; see Fig. 6. The oil tended to be separated into different phases. Clear water was observed at the bottom, while a second black phase was seen to be floating; a third very viscous phase lay at the bottom. The analysis of oil is complex and was not made.

\subsubsection{Solid residue}

The vertical shrinkage of the bed was as low as 3.5\% of its initial height. After cooling of the experiment, the bed was sampled in horizontal slices. The solid residue was homogeneous in color, a very clear grey. Nevertheless, a 1-2 mm-thick layer of unburned particles (dark grey color) was observed at the walls of the cell, all along the height of the cell. This indicates that the temperature at the cell walls was too low for combustion to occur.

No liquid oil deposited at the surface of the grains or impregnating the grains was observed. The particles were not sticky and had no smell, while the flue gas had a very strong smell.

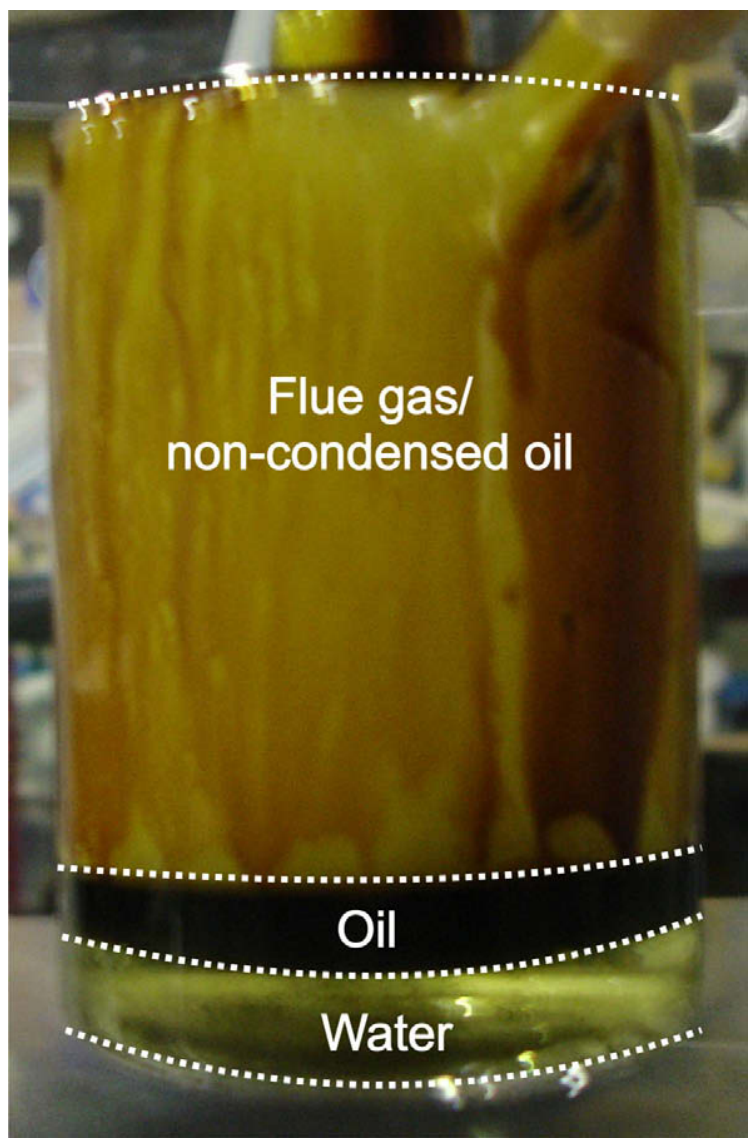

Fig. 6. Shale oil recovery during experiments.

\subsection{Temperature}

The values obtained at different locations inside the bed are reported in Fig. 7a. For thermocouple T1, close to the bed surface, a peak at about $750{ }^{\circ} \mathrm{C}$ was observed. After ignition at the surface, a combustion front started to self-propagate downward in cocurrent through the bed. For the other thermocouples placed along the axis (T2, T3, T10, T11 and T12), peaks at a temperature near $1100{ }^{\circ} \mathrm{C}$ were observed. This temperature is comparable to that obtained during the calibration tests made with a mix of charcoal/ sand, where the amount of FC was similar. 

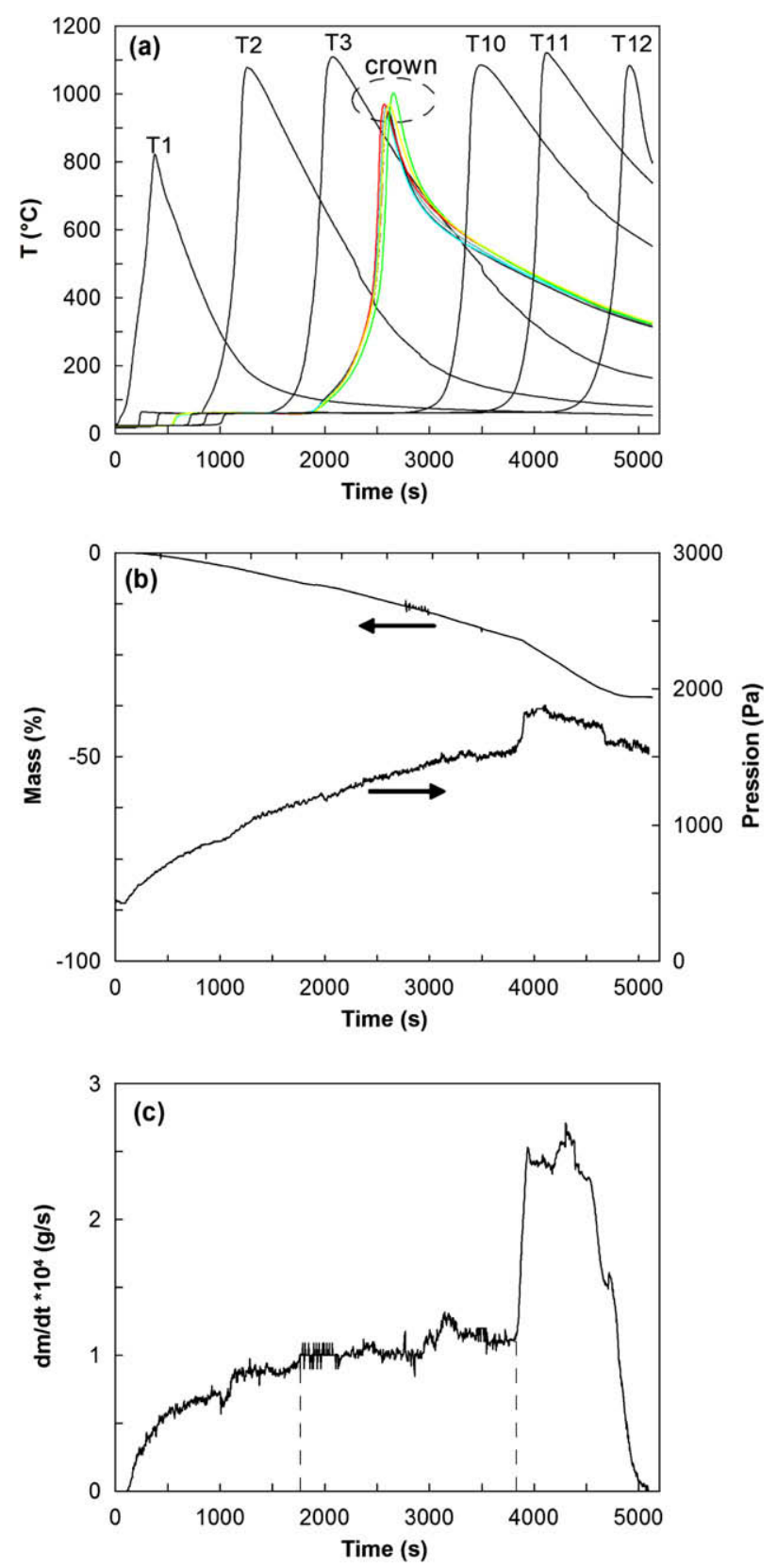

Fig. 7. (a) Temperature evolution of the thermocouples placed along the axis (T1, T2, T3, T10, T11 and T12) and placed a horizontal cross section (crown). (b) Mass and pressure evolution in the bed. (c) Derivative of the mass evolution in the bed

On the horizontal cross section at mid-height of the bed and $11 \mathrm{~mm}$ away from the wall (crown thermocouples, T4-T9), one can see that the peak temperature was about $180^{\circ} \mathrm{C}$ lower than at the axis. This reveals again that a pure 1D situation was not achieved, which can be attributed to significant heat loss at the walls of the cell.

A global heat balance was established to estimate the heat loss over all the combustion process; the details of the calculation are given in the Appendix. It was found that approximately $42 \%$ of the heat released by the combustion of the FC of oil shale was lost. Despite the quite large diameter of the fuel bed $(91 \mathrm{~mm})$ and the thickness of the insulation material around it, the heat losses were not negligible. This observation indicates that in experiments from the literature where the combustion front is observed in non-insulated transparent smaller-diameter reactor tubes, the heat losses were much higher, and significantly affected the front structure

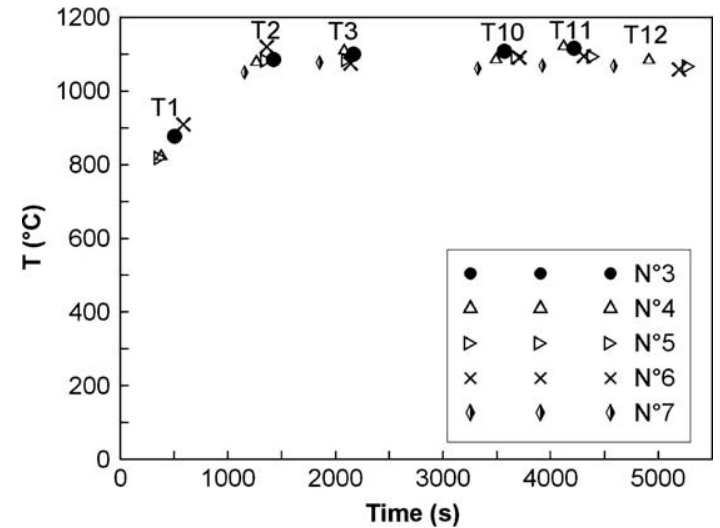

Fig. 8. Axial temperature peak for five trials.

and propagation. The reader can find detailed experimental and theoretical work about the effect of heat losses on opposed smoldering, and on critical conditions to achieve a self sustaining combustion front, both in microgravity and in normal gravity [6].

The heating rate inside the bed at the arrival of the front was between 60 and $90 \mathrm{~K} \mathrm{~min}^{-1}$. This is much higher than the operating rate in a standard TG experiment, but it is within the operational range of the horizontal tube furnace, Submitted paper [26], that was used to determine the amount of FC: $50-900 \mathrm{~K} \mathrm{~min}^{-1}$.

Fig. 7a also shows a very clear phenomenon observed during the experiments. The temperatures at different positions of the bed all stabilized at a very constant temperature of $60^{\circ} \mathrm{C}$ until the combustion front approached. This can be compared with the observation of a DTG peak at the same temperature of $60^{\circ} \mathrm{C}$ during the test at $10 \mathrm{~K} \mathrm{~min}^{-1}$, Submitted paper [26]. It is probable that this peak is due to an endothermic phase change that was not identified.

Observing the dispersion of results during repeatability tests brought some insight into the mechanisms involved. In the case of oil shale/sand tests, the difference between the peak times at a given location, Fig. 8, might be explained by the complex flow developed in the cell, caused by the conversion of solid kerogen into liquid oil and then into gas, [28], generating overpressures in the bed. This clogging results in disturbance of fluid flow across the porous medium. One can verify this by observing Fig. 4 for charcoal/sand tests: for the "simple" medium, the temperature peak time results are coincident when the test is repeated.

Fig. 9 shows axial temperature profiles along the reactor axis at different times. These profiles were obtained by plotting - at the peak time for each thermocouple - the temperature values for all thermocouples. Extrapolation curves around each thermocouple were obtained from the temperature values before and after the peak time. The front velocity was used to calculate the position $Z$ of the thermocouple relative to the Temperature Peak Point (TPP) at each time. The temperature decrease downstream of the TPP (right hand side of TPP) keeps quite a constant shape at different times, while the hot zone upstream of the front becomes larger as the front progresses.

\subsection{The structure of the combustion front}

\subsubsection{Thermal structure}

From the temperature profile at a given time $(4119 \mathrm{~s}$ for instance), a first geometrical description of the front structure can be established, as follows:

- If one assumes that drying is completed rapidly when the temperature reaches $150^{\circ} \mathrm{C}$, the drying zone can be localized 


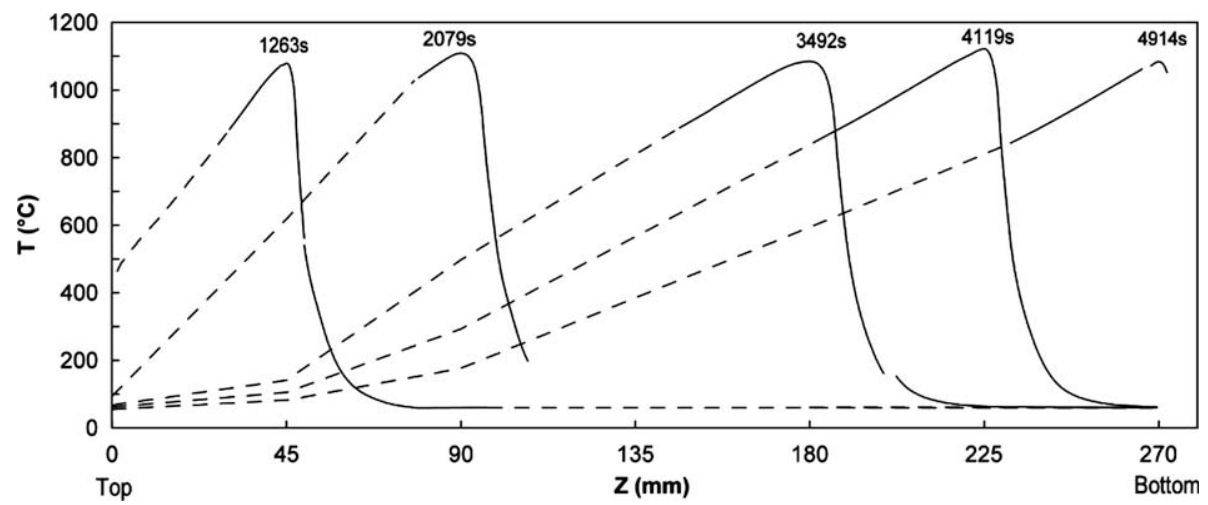

Fig. 9. Axial temperature profiles along the axis of the cell at different times.

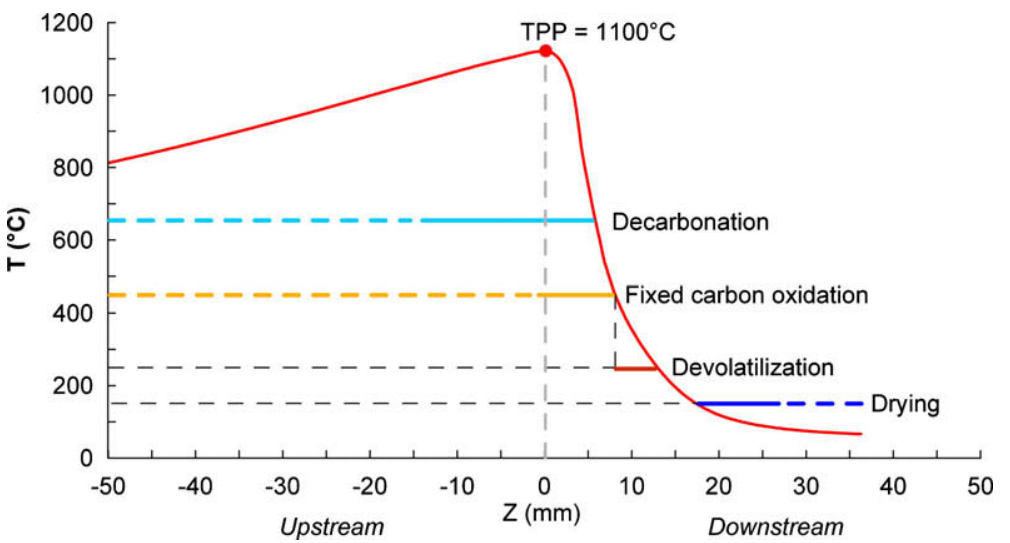

Fig. 10. Front structure evaluated from temperature profile.

downstream of the TPP, starting $18 \mathrm{~mm}$ from the TPP as illustrated in Fig. 10 where $Z$ was fixed to 0 at the TPP.

- The DTA tests performed under $\mathrm{N}_{2}$ in Submitted Paper [26] showed that devolatilization progresses significantly as the temperature reaches $250{ }^{\circ} \mathrm{C}$, and is very fast at $550{ }^{\circ} \mathrm{C}$. Consequently, the devolatilization zone can be localized between 7 and $13 \mathrm{~mm}$ downstream the TPP; its thickness is as small as $6 \mathrm{~mm}$.

- Carbon oxidation under air has been extensively studied, and is known to progress significantly above $450{ }^{\circ} \mathrm{C}$ and rapidly at $550^{\circ} \mathrm{C}$. But for $\mathrm{FC}$ oxidation to occur, oxygen must be also present. Air is fed from upstream of the combustion front (small $Z$ ), and several percent of $\mathrm{O}_{2}$ are still present at the exit of the cell. The zone where the two criteria are satisfied ranges from very small $Z$ to $Z=8 \mathrm{~mm}$. Nevertheless, at small $Z$, there is no more FC present as shown by the characterization of the solid residue in Submitted Paper [26]. It is not possible at this stage to localize where the oxidation has the highest rate, although this is probably around the TPP.

- The DTA tests performed in Submitted Paper [26] showed that decarbonation of carbonates operates at a significant rate from a temperature of $650^{\circ} \mathrm{C}$ and was very rapid at $750^{\circ} \mathrm{C}$. The decarbonation zone is thus possibly located upstream of the TPP, and also downstream, along $6 \mathrm{~mm}$.

\subsubsection{Direct observation of the front}

In an experiment, the combustion process was quenched with $\mathrm{N}_{2}$, freezing the combustion front at mid-height of the cell. After impregnating the porous medium with a resin, vertical cuts were made. It was possible from this experiment to visualize a clear dif- ference in the color of the medium before and after passage of the front; Fig. 11 shows the photograph. The thickness of the transition zone is 3-6 times the average particle size. Nevertheless, it remains difficult to interpret this image in terms of thickness of the reaction zones.

\subsubsection{Chemical structure}

The chemical thickness of the front was also investigated using the micro-sampling system. Fig. 12 summarizes the results obtained in term of the composition of the gas at different locations inside the front. It was particularly difficult to sample the eight syringes over the appropriate period of time, i.e. when the front is passing at the sampling point inside the cell. Indeed, the front

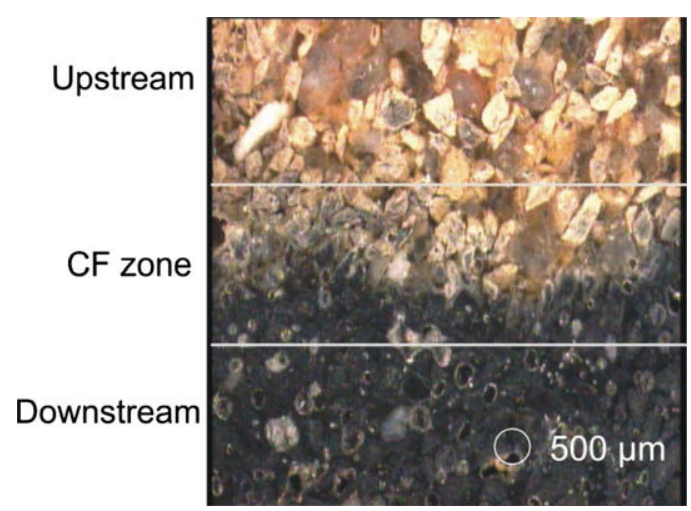

Fig. 11. Photography of combustion front. 


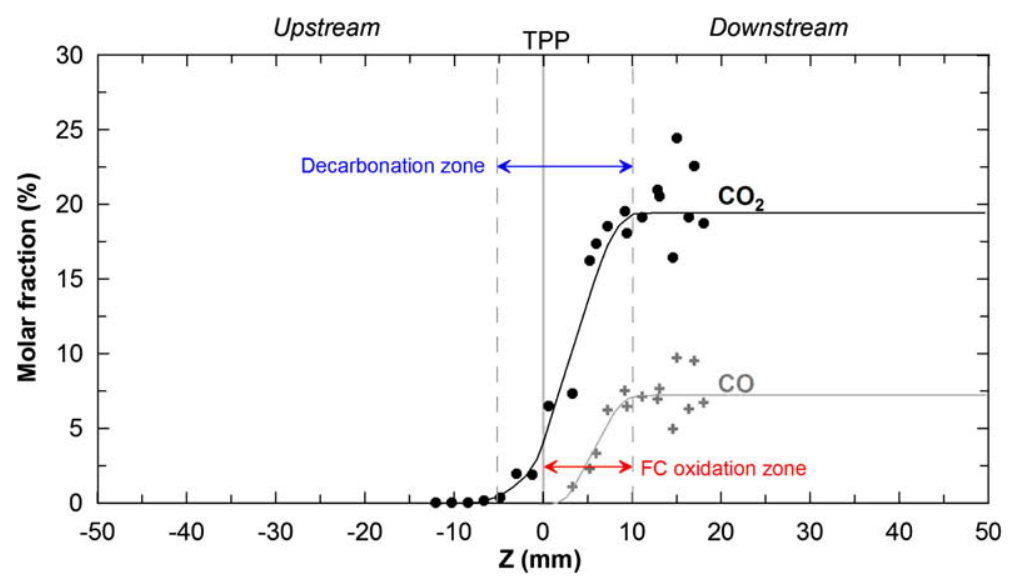

Fig. 12. Results from different experiments with micro-sampling.

was not a plane surface and not horizontal as described later. In order to put together the results from different experiments, the experimental values are represented with space as the $X$ scale, and relative to the TPP. Again the position of micro-sampling relative to the TPP was calculated from the time separating sampling and peak temperature occurrence at the sampling point, using the front velocity. As can be seen in Fig. 12, the results are quite scattered. Nevertheless, the average value of the $\mathrm{CO}_{2}$ fraction downstream of the front (left hand side) is around $20 \%$, corresponding to the value obtained sampling the flue gas at the exit of the cell (19\%), Martins et al. [26].

- As far as CO is concerned, its origin is FC oxidation only. The amount of $\mathrm{CO}$ released by devolatilization is negligible when compared with CO formed by FC oxidation, Martins et al. [26]. From the observation of the curve, it can be established that the oxidation is essentially concentrated in the zone up to $10 \mathrm{~mm}$ downstream of the TPP. This is compatible with the first description proposed before. It is now possible to locate the upstream limit of the oxidation zone at the TPP: in all probability there is no more FC upstream of this point.

- $\mathrm{CO}_{2}$ originates from the oxidation of $\mathrm{FC}$ but also from the decarbonation of calcite, in significant proportion, Martins et al. [26]. The plot indicates that $\mathrm{CO}_{2}$ is formed in a zone slightly larger than the zone for $\mathrm{CO}$ formation: the decarbonation zone spreads from $5 \mathrm{~mm}$ upstream of the TPP, where the temperature is as high as $1100^{\circ} \mathrm{C}$. The fact that $\mathrm{CO}_{2}$ is not released upstream of this point indicates that carbonates are not present anymore, i.e. the decarbonation has been completed. As far as the downstream limit of this zone is concerned, it seems not to extend further than $10 \mathrm{~mm}$ downstream of the TPP.

\subsubsection{Shape of the front}

Significant time duration separates the passage of the front (Fig. 7a) at the different thermocouples of the horizontal crown: the combustion front is thus not horizontal but inclined. From the propagation front velocity, and from the time separating the first peak and the last peak of the thermocouples crown, the slope of the front was evaluated at $4^{\circ}$, varying between $1^{\circ}$ and $7^{\circ}$ during repeatability tests. The fact that the front was not a horizontal surface may result from a non-uniform radiative heat flux during ignition. This explanation, however, cannot stand because the front remained a horizontal surface during the combustion of a mix of charcoal and sand. Therefore, a complex situation involving gas/ oil condensation and re-evaporation is likely to be responsible for the front inclination in the case of oil shale. Instabilities due to the ignition process may also explain the front inclination.
Moreover, looking at the results in Fig. 7a, it is clear that the front reached the first thermocouple of the crown earlier than it reached the axis of the cell at the same $Z$, i.e. midway between the time for T3 peak and the time for T10 peak. This result indicates that the front was not a plane surface, but a curved surface with the top at the axis of the cell. Consequently, a front shape can be proposed illustrated in Fig. 13, where three locations (o) were plotted of the temperature peak at the time when the front passes at the axis of the cell at $Z=135 \mathrm{~mm}$. One explanation might be that the front progress is controlled by $\mathrm{O}_{2}$ supply, as demonstrated in Martins et al. [26]. The mass flow rate of $\mathrm{O}_{2}$ close to the cold walls is higher than at the axis. There are several reasons for this:

- the density of $\mathrm{O}_{2}$ is higher due to the lower temperature;

- the viscosity is smaller, also due to the lower temperature;

- the arrangement of particles in contact with the walls is not as dense as in the rest of the cell.

This might explain the more rapid progress of the front at the walls of the combustion cell.

\subsection{Pressure drop of the particle bed}

As illustrated in Fig. 7b, the pressure at the top of the bed first progressively increases from 500 to $1500 \mathrm{~Pa}$. After that, one can observe a sudden increase to $1800 \mathrm{~Pa}$ and a rapid decrease at the end of the test. The progressive increase might be explained by two phenomena:

(i) The temperature increase of the medium, as was confirmed from the experiments with charcoal/sand.

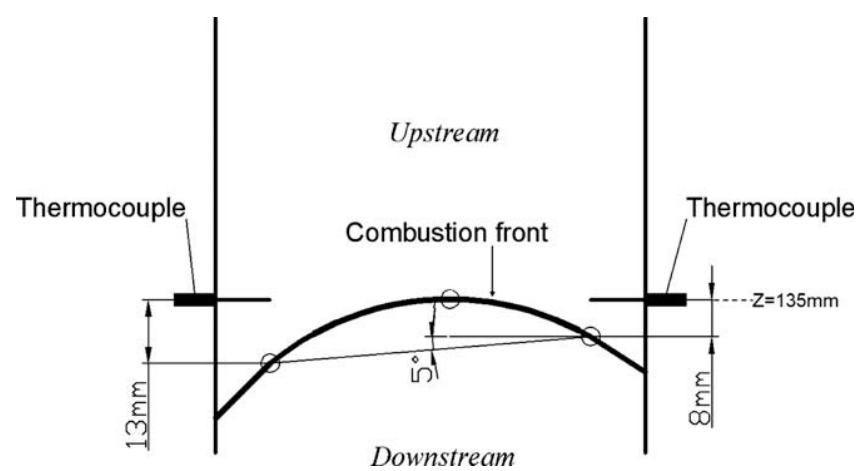

Fig. 13. Shape of the front. 
(ii) The progressive formation of an oil bank downstream of the combustion front, or the clogging of the medium by oil deposits and porosity decrease. By the end of the test, the oil is evacuated at the bottom of the cell, explaining the rapid decrease in the pressure. Indeed, a flow of liquid oil at the bottom of the cell was observed starting at $t=3490 \mathrm{~s}$, i.e. some time before the sudden pressure increase.

\subsection{Mass loss of the particle bed}

The evolution of the fuel bed mass is reported in Fig. 7b. It is shown here that when liquid oil arrives at the bottom of the cell, it is evacuated to a container and not weighed with the rest of the cell. It is clear that the mass loss rate (slope of the curve) was not constant along the process. After $4900 \mathrm{~s}$, the mass stopped decreasing.

The derivative of fuel bed mass gives a better reading. It was calculated using the recorded mass data and by smoothing the curve with a time step of $15 \mathrm{~s}$; the results are shown in Fig. 7c. Looking carefully at the results, one can distinguish three domains along the process:

(i) A starting domain, up to $1750 \mathrm{~s}$ during which the mass loss rate increases. This is attributed to the fact that the front at the very beginning is not hot enough to cause calcite decarbonation.

(ii) A more or less stable propagation domain, from $t=1750 \mathrm{~s}$ to $t=3800 \mathrm{~s}$. Along this domain, the mass loss rate increases by only $14 \%$.

(iii) A perturbed domain after $3800 \mathrm{~s}$, in which the mass loss rate suddenly increases and then rapidly decreases.

It is interesting to note that these three domains can also be observed - with time synchronization - on the bed top pressure curve. This would corroborate the explanation of the oil bank evacuation by the end of the process, explaining both the pressure drop loss and the high mass loss rate.

\subsection{The front velocity}

The front velocity calculated from the times of TPP at the different thermocouples on the axis is reported in Fig. 14 for all experiments. The results for the reference experiment are highlighted using a bold line. The front propagation velocity is $3.1 \mathrm{~mm} \mathrm{~min}^{-1}$ at the beginning of the experiment, and increases to $4.0 \mathrm{~mm} \mathrm{~min}^{-1}$ at the end. For the charcoal/sand tests, the propagation front velocity at the beginning

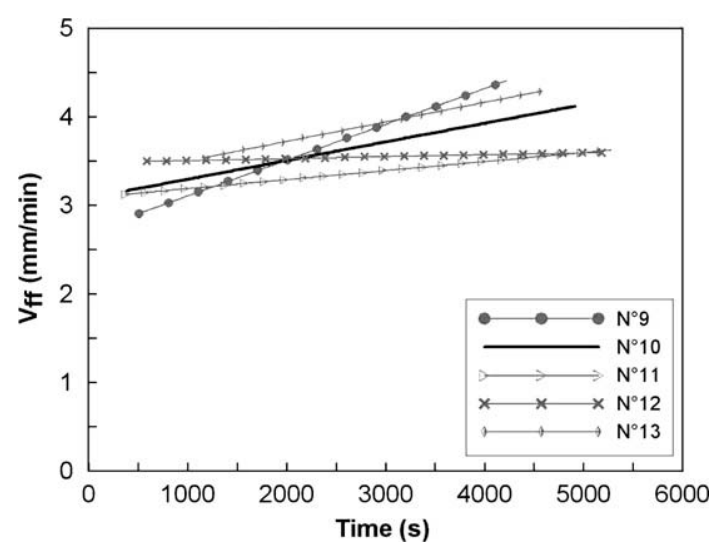

Fig. 14. Repeatability trials of the combustion cell.

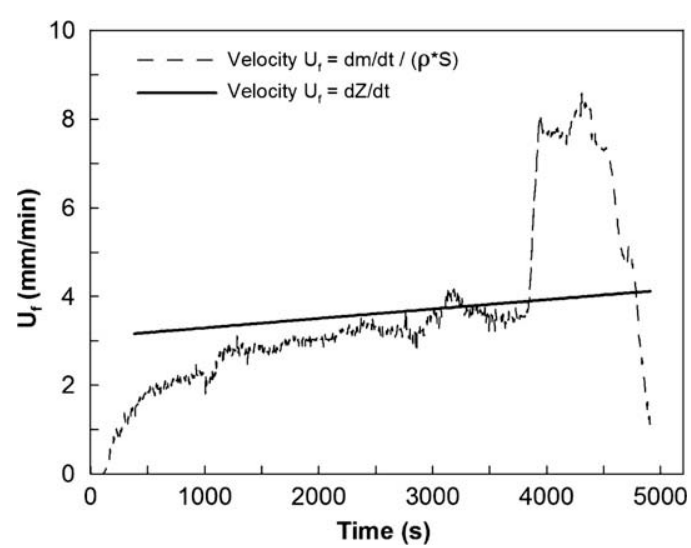

Fig. 15. Two approaches to evaluate the front velocity.

was about $3.21 \mathrm{~mm} \mathrm{~min}^{-1}$ and at the end it increased to $4.84 \mathrm{~mm} \mathrm{~min}^{-1}$. These results are consistent since the mass fraction of FC was comparable for the two media. These values are characteristic of the smoldering propagation velocity. The repeatability tests for oil shale/sand combustion show that the increase in the velocity of the front is always observed, although some differences can be seen from one test to another.

\subsection{The physical state of the oil}

It is difficult to establish under what physical state - gas or liquid, adsorbed or not on the solid oil shale particles - the oil is transported through the porous medium downstream of the front. Eq. (1) should be valid if there is no accumulation of matter (here, oil) inside the bed. The apparent density of the oil shale/sand mix was measured before $\left(\rho_{i}\right)$ and after $\left(\rho_{p}\right)$ the passage of the front, and $U_{f}$ was calculated and plotted in Fig. 15. $U_{f}$ calculated from the position of the TPP was also plotted in Fig. 15 as the actual front velocity.

$U_{f}\left(\rho_{i}-\rho_{p}\right)=\frac{d m}{d t}$

The figure indicates that the front velocity as calculated from Eq. (1) is first lower than the actual velocity: this indicates that accumulation of oil occurs during this phase of the propagation process. Later on, as the front progresses, accumulation of oil is no longer possible; the oil is driven out from the cell by the end of the experiment, when the velocity deduced from Eq. (1) becomes higher than the actual velocity. A specific experiment was made to obtain information about the physical state of oil adsorbed in the porous medium. This experiment was stopped as the front reached the mid-height of the cell by switching the air feed to $\mathrm{N}_{2}$. No liquid oil was observed; the oil is adsorbed at the surface of the solid particles. Nevertheless, this result does not eliminate the possibility that when the front progresses further in the cell, the liquid oil can be present.

\section{Conclusion}

By means of the new 1D experimental device, the propagation of a combustion front with forward air fed at $14601 \mathrm{~min}^{-1} \mathrm{~m}^{-2}$ STP was characterized in detail along $300 \mathrm{~mm}$ of a $75 / 25 \mathrm{wt}$. mix of oil shale/sand. The experiments were repeatable. The combustion regime was complete gasification. The progress of the front was limited by the air supply. 
Despite the relatively large diameter of the cell and the good thermal insulation, the heat losses were estimated at $42 \%$ of the heat released by the combustion.

When using a model medium composed of charcoal and sand, the front propagates as a horizontal plane surface, with a progressively increasing velocity. Using oil shale/sand as the fuel, after $150 \mathrm{~mm}$ of progress the combustion front inside the bed was an inclined curved surface with its top close to the axis of the cell. Consequently, this deformation and inclination can be attributed to phenomena specific to oil shale. This specific behavior was confirmed by a larger dispersion of results among the tests obtained in the case of oil shale combustion than for charcoal/sand mix combustion.

From the temperature profiles established, a geometrical description of the successive zones of drying, devolatilization, char oxidation and carbonate decarbonation can be proposed. The new setup enabling micro-sampling of gases inside the front confirmed that the chemical thickness of the oxidation front is about $10 \mathrm{~mm}$.

Condensation of liquid oil at the exit of the cell was observed when the front reached approximately $Z=170 \mathrm{~mm}$. It was shown that oil is accumulated in the porous medium at the beginning of the experiment, although stopping an experiment at mid time did not show the presence of liquid oil in the medium. By the end of the experiment, oil is expulsed from the cell. It could not be established here if liquid oil - a third phase - did form inside the medium.

\section{Acknowledgements}

This work was partly supported by the CNRS through the research project "ACI combustion en milieu poreux", supervised by the Laboratoire de Combustion et de Détonique, Futuroscope FRANCE. The authors wish to thank them here.

The authors would also like to thank Bernard Auduc for help in the design and assembly of the experiments.

\section{Appendix. Energy balance over an experiment}

The total heat loss of the combustion cell can be estimated as the sum:

- of the heat lost at the external walls of the cell;

- and the heat necessary to heat the cell and the fuel from the initial room temperature to its final average temperature.

The loss at the external walls was calculated as follows:

$Q_{\text {wall }}=h S\left(T_{p}-T_{a m b}\right) t$

where,

- the heat transfer coefficient by natural convection $\mathrm{h}$ was estimated at $15 \mathrm{~W} \mathrm{~m}^{-2} \mathrm{~K}^{-1}$;

- the external surface of the cell $\mathrm{S}$ was estimated at $0.251 \mathrm{~m}^{2}$;

- the average temperature of the external surface $T_{p}$ was measured at $60{ }^{\circ} \mathrm{C}$;

- the ambient temperature $T_{a m b}$ was $18{ }^{\circ} \mathrm{C}$;

- the time $t$ was estimated at half the duration of an experiment, or $2500 \mathrm{~s}$, since the external surface at a given level of the cell is hot only when the front has passed through.

The energy to heat the combustion cell from the room temperature $T_{a m b}$ to the average final temperature $T_{p}$ can be expressed:

$Q_{\text {cell }}=m C p\left(T_{p}-T_{a m b}\right)$

where,
- $m$ is the mass of the cell and fuel, $5.0 \mathrm{~kg}$;

- $C p$ is taken as the specific heat of the insulation material, estimated at $1386 \mathrm{~J} \mathrm{~kg}^{-1} \mathrm{~K}^{-1}$.

The total heat loss is then $Q_{\text {tot }}=Q_{\text {wall }}+Q_{\text {cell }}=291+396=687 \mathrm{~kJ}$.

The FC in the cell was oxidized as follows:

$\mathrm{C}+\left[\frac{f r}{2}+(1-f r)\right] \mathrm{O}_{2} \rightarrow$ fr $\mathrm{CO}+(1-f r) \mathrm{CO}_{2}$

The calorific value for this reaction is $\Delta H_{o x}=19470 \mathrm{~kJ} / \mathrm{kg}$ for $f r=0.565$ following Martins et al. [26].

The total mass of FC oxidized was $m_{\mathrm{FC}-\mathrm{ox}}=84.2 \mathrm{~g}$, Martins et al. [26].

The energy released by the combustion of the FC was:

$Q_{o x}=m_{F C-o x} \cdot \Delta H o x=1640 \mathrm{~kJ}$

The fraction of lost energy was then

$F r_{\text {lost }}=$ Qtot $/$ Qox $=0.42$

\section{References}

[1] Palmer KN. Smouldering combustion in dusts and fibrous materials. Combust Flame 1957;1(2):129-54

[2] Hobbs ML, Radulovic PT, Smoot LD. Combustion and gasification of coals in fixed-beds. Prog Energy Combust Sci 1993;19(6):505-86.

[3] Ohlemiller TJ. Modeling of smoldering combustion propagation. Prog Energy Combust Sci 1985;11(4):277-310.

[4] Torero JL, Fernandez-Pello AC. Forward smolder of polyurethane foam in a forced air flow. Combust Flame 1996;106(1-2):89-109.

[5] Fatehi M, Kaviany M. Adiabatic reverse combustion in a packed bed. Combust Flame 1994;1(99):1-17.

[6] Bar-Ilan A, Rein G, Fernandez-Pello AC, Torero JL, Urban DL. Forced forward smoldering experiments in microgravity. Exp Therm Fluid Sci 2004;28(7): 743-51.

[7] Vantelon J-P, Lodeho B, Pignoux S, Ellzey JL, Torero JL. Experimental observations on the thermal degradation of a porous bed of tires. Proc Combust Inst 2005;30(2):2239-46.

[8] Ryu C, Yang YB, Khor A, Yates NE, Sharifi VN, Swithenbank J. Effect of fuel properties on biomass combustion: part I. Experiments - fuel type, equivalence ratio and particle size. Fuel 2006;85(7-8):1039-46.

[9] Yang YB, Ryu C, Khor A, Yates NE, Sharifi VN, Swithenbank J. Effect of fue properties on biomass combustion. Part II. Modelling approach - identification of the controlling factors. Fuel 2005;84(16):2116-30.

[10] Yang YB, Ryu C, Khor A, Sharifi VN, Swithenbank J. Fuel size effect on pinewood combustion in a packed bed. Fuel 2005;84(16):2026-38.

[11] Khor A, Ryu C, Yang YB, Sharifi VN, Swithenbank J. Straw combustion in a fixed bed combustor. Fuel 2007;86(1-2):152-60.

[12] Wang JH, Chao CYH, Kong W. Experimental study and asymptotic analysis of horizontally forced forward smoldering combustion. Combust Flame 2003;135(4):405-19.

[13] Thunman H, Leckner Bo. Co-current and counter-current fixed bed combustion of biofuel - a comparison. Fuel 2003;82(3):275-83.

[14] Akkutlu IY, Yortsos YC. The dynamics of in-situ combustion fronts in porous media. Combust Flame 2003;134(3):229-47.

[15] Castanier LM, Brigham WE. Upgrading of crude oil via in situ combustion. J Petrol Sci Eng 2003;39(1-2):125-36.

[16] Pironi P, Switzer C, Rein G, Gerhard JI, Torero JL, Fuentes A. Small-scale forward smouldering experiments for remediation of coal tar in inert media. Proc Combust Inst 2009; 32. doi:10.1016/j.proci.2008.06.184.

[17] Gort R, Valk M, Brem G. Solid fuel combustion in a laboratory grate furnace. In: Proceedings of third AsianPacific symposium on combustion and energy utilization. Hongkong; 1995.

[18] Shin D, Choi S. The combustion of simulated waste particles in a fixed bed. Combust Flame 2000;121(1-2):167-80.

[19] Liang L, Sun R, Fei J, Wu S, Liu X, Dai K, et al. Experimental study on effects of moisture content on combustion characteristics of simulated municipal solid wastes in a fixed bed. Bioresource Technol 2008;99(15):7238-46.

[20] Thunman H, Leckner B. Influence of size and density of fuel on combustion in a packed bed. Proc Combust Inst 2005;30(2):2939-46.

[21] Zhou H, Jensen AD, Glarborg P, Jensen PA, Kavaliauskas A. Numerical modeling of straw combustion in a fixed bed. Fuel 2005;84(4):389-403.

[22] Saoiabi A, Doukkali A, Hamad M, Zrineh A, Ferhat M, Debyser Y. Schistes bitumineux de Timahdit (Maroc): composition et propriétés physicochimiques Timahdit (Morocco) oil shales: composition and physicochemical properties. Comptes Rendus de l'Académie des Sciences - series IIC - chemistry 2001;4(5):351-60.

[23] Saoiabi A, Doukkali A, Hamad M, Zrineh A, Ferhat M, Debyser Y. Comportement thermique des schistes bitumineux de Timahdit (Maroc)Thermal behaviour of the Timahdit (Morocco) oil shales. Comptes Rendus de l'Académie des Sciences - series IIC - chemistry 2001;4(5):361-6. 
[24] Sadiki A, Kaminsky W, Halim H, Bekri O. Fluidised bed pyrolysis of Moroccan oil shales using the hamburg pyrolysis process. J Anal Appl Pyrol 2003;70(2): 427-35.

[25] Debenest G, Mourzenko VV, Thovert J-F. Smoldering in fixed beds of oil shale. Combust Theory Model 2005;9:113-35.

[26] Martins MF, Salvador S, Thovert J-F, Debenest G. Co-current combustion of oil shale - part 1: characterisation of the solid and gaseous products. Fuel 2009;89(1):144-51.
[27] Al-Saffara H, Priceb D, Soufia A, Hughesa R. Distinguishing between overlapping low temperature and high temperature oxidation data obtained
from a pressurised flow reactor system using consolidated core material. Fuel 2000;79(7):723-32.

[28] Hansom J, Lee M-K. Effects of hydrocarbon generation, basal heat flow and sediment compaction on overpressure development: a numerical study. Petrol Geosci 2005;11(4):353-60. 